\title{
INOVASI PELAYANAN PUBLIK LUKADESI (KELUARGA BERDUKA DESA SIAGA) DI SLEMAN D.I. YOGYAKARTA
}

\section{PUBLIC SERVICE INNOVATION OF LUKADESI (GRIEVING FAMILIES VILLAGE ALERT) IN SLEMAN D.I. YOGYAKARTA}

\author{
Hendy Setiawan \\ Universitas Gadjah Mada Yogyakarta, Indonesia \\ E-mail: hendysetiawan357gmail.com
}

\begin{abstract}
Lukadesi's innovation was created to society that is aware of population administration. This is because when a death event occurs, people are reluctant to report to related parties so that the population data in the database does not match the number of people in the field. As a result, data held by the Office of Population and Civil Registration of Sleman Regency are inaccurate. In addition, Lukadesi's is intended to relieve people who have experienced death, because a death certificate can be issued before the body is buried. The purpose of this study is to analyze lukadesi innovation in Sleman using the theory of innovation attributes, which include: relative advantage, compatibilty, complexity, triability, and observability. This research method uses descriptive qualitative data collection techniques by interview and observation. The results show that Lukadesi's innovation became the village's flagship service that was formed in mid 2017 and to date 83 villages out of 86 villages in Sleman Regency have participated in Lukadesi. This innovation is able to raise awareness of the administration of public deaths in Sleman Regency which reaches more than 80\%, so that the data in the population database of the Population and Civil Registry are more accurate.
\end{abstract}

Keywords: innovation; lukadesi; public services

\begin{abstract}
ABSTRAK
Inovasi pelayanan publik Lukadesi diciptakan agar masyarakat sadar administrasi kependudukan. Hal ini dikarenakan ketika terjadi peristiwa kematian masyarakat enggan melaporkan ke pihak terkait sehingga data kependudukan yang ada di database tidak sesuai dengan jumlah masyarakat di lapangan. Akibatnya data yang dimiliki oleh Dinas Kependudukan dan Pencatatan Sipil Kabupaten Sleman kurang akurat. Selain itu inovasi Lukadesi ditujukan untuk meringankan masyarakat yang mengalami peristiwa kematian, karena surat kutipan akta kematian dapat terbit sebelum jenazah disemayamkan. Tujuan dari penelitian ini untuk menganalisis inovasi lukadesi di Kabupaten Sleman dengan teori atribut inovasi meliputi: keuntungan relatif, kesesuaian, kerumitan, kemungkinan dicoba, dan kemudahan diamati. Metode penelitian ini menggunakan kualitatif deskriptif dengan teknik pengumpulan data dengan cara wawancara dan observasi. Hasil menunjukkan inovasi Lukadesi menjadi layanan unggulan desa yang dibentuk pada pertengahan 2017 dan sampai saat ini sudah 83 desa dari 86 desa yang ada di Kabupaten Sleman menjadi
\end{abstract}

Journal of Governance and Local Politics (JGLP) 
peserta Lukadesi. Inovasi ini mampu menumbuhkan kesadaran administrasi kematian masyarakat di Kabupaten Sleman yang mencapai 80\% lebih, sehingga data yang ada pada database kependudukan Dinas Kependudukan dan Pencatatan Sipil lebih akurat dibandingkan sebelum adanya inovasi Lukadesi.

Kata kunci: inovasi; lukadesi; pelayanan publik

\section{PENDAHULUAN}

Penelitian ini bertujuan untuk menganalisis lebih dalam terkait inovasi pelayanan publik yang menjadi unggulan di Kabupaten Sleman yakni inovasi Lukadesi. Lukadesi di Kabupaten Sleman menjadi fokus yang menarik untuk diteliti, karena inovasi ini menjadi satu-satunya inovasi yang ada di Indonesia dibidang penerbitan kutipan akta kematian secara cepat dan transparan dengan melibatkan desa-desa yang ada di Kabupaten Sleman sebagai mitra inovasi pelayanan tanpa membebani masyarakat yang berduka. Selain itu, inovasi ini sangat berhasil diterapkan dengan partisipasi masyarakat dengan animo lebih dari 90\%. Adanya Lukadesi mampu memperbaiki data di database kependudukan dengan akurat mengingat sebelum adanya Lukadesi data kependudukan tidak sesuai di lapangan sehingga ketika diadopsi ketika pemilu menimbulkan pemilih ganda atau pemilih hantu. Oleh karena itu Lukadesi sangat menarik diteliti karena banyak inovasi pelayanan yang dalam perencanaanya kurang matang sehingga dalam implementasinya banyak hambatannya.

Misalnya berdasarkan penelitian yang dilakukan oleh Pebriani dan Rohman (2019) terhadap inovasi pelayanan publik di Dinas Kependudukan dan Pencatatan Sipil di Kota Malang melalui inovasi Gampil “Gesit Aktif Merakyatnya Dinas Kependudukan dan Pencatatan Sipil” menunjukkan bahwa adanya upaya untuk memotong dan memangkas standar operasional prosedur yang ada. Hal ini dikarenakan jika mengacu pada SOP yang ada maka pelayanan dinilai akan lebih lama, mahal, berlarut-larut, dan menimbulkan kerumitan di tengah masyarakat. 
Inovasi ini memiliki hambatan yakni dari aspek sosialisasi yang belum masif, dan kurangnya jumlah pegawai yang ada pada dinas tersebut.

Selain itu, kendala inovasi yang muncul diperkuat dengan penelitian yang dilakukan oleh Putra (2018) Melalui Home Care di Kota Makassar dapat diketahui bahwa inovasi pelayanan publik dalam implementasinya memberikan kemudahan masyarakat dalam akses layanan kesehatan di mana setidaknya sudah ada 48 Puskesmas yang mengimplementasikan inovasi Home Care ini seKota Makassar di tahun 2015 dengan jumlah pengguna sebanyak 3379 orang di tahun 2016. Inovasi Home Care ini memiliki keunggulan seperti home care Visited, Home Care Follow Up, dan Home Care Emergency. Inovasi ini memiliki kendala misalnya kesiapan sopir ambulan pada saat tengah malam ketika dibutuhkan masyarakat terkait kebutuhan layanan kesehatan. Walaupun demikian, secara keseluruhan sudah berhasil diimplementasikan dengan baik.

Walaupun inovasi pelayanan melahirkan banyak kendala namun banyak juga yang memberikan manfaat besar jika inovasi pelayanan dirancang secara matang. Misalnya mengacu pada penelitian Ariyani dkk (2020) tentang inovasi "Suroboyo Bis" di Kota Surabaya menunjukkan hasil efektif. inovasi ini mampu mengurangi kemacetan yang ada di Surabaya karena masyarakat dimobilisasi untuk menggunakan palayanan umum dengan fasilitas yang nyaman. Melalui penggunaan layanan umum ini masyarakat tidak perlu menggunakan kendaraan pribadi jika tidak mendesak mengingat kemacetan di Surabaya cukup padat. Keberhasilan inovasi juga didasarkan pada penelitian yang dilakukakn oleh Choiriyah dan Chabibi (2020) tentang inovasi pelayanan publik dalam pelaporan kerusakan jalan melalui aplikasi M-Bonk. Hasil penelitian menunjukkan jika inovasi M-Bonk memberikan dampak positif di mana aduan pelayanan publik yang disampaikan dari masyarakat langsung direspon dan ditindaklanjuti secara cepat. adanya kemudahan aplikasi ini memuadahkan masyarakat untuk memberikan aduhan keluhan pelayanan publik yang ada. 
Penelitian tersebut menjadi dasar betapa pentingnya inovasi pelayanan disektor publik dengan mempertimbangkan perencanaanya secara terstruktur dan sistematis. Hal tersebut didukung dengan Undang-Undang Nomor 23 Tahun 2014 mengamanatkan bahwa inovasi merupakan aspek yang sangat mendesak dilakukan dalam penyelenggaraan pemerintahan khususnya pelayanan publik mengingat baik buruknya penyelenggaraan pemerintahan dapat diamati dari banyaknya inovasi-inovasi yang dimiliki oleh pemerintah dalam penyelenggaraan pemerintahan. Pemerintah sebagai penyedia layanan publik baik barang ataupun jasa publik mulai gencar melakukan inovasi-inovasi dalam pelayanan publik sejak diimplementasikanya kebijakan desentralisasi dan otonomi daerah dengan tetap mengacu pada regulasi Undang-undang Nomor 23 tahun 2014 tentang Pemerintahan Daerah. Hal tersebut dilakukan mengingat pelayanan tidak bisa dipisahkan dari kehidupan masyarakat sehingga pemerintah dituntut untuk menciptakan pelayanan yang merata dan berkeadilan (Djamrut, 2015:1473).

Tuntutan publik yang semakin besar mengindikasikan bahwa persoalan pelayanan publik masih jauh dari harapan, bahkan banyak masyarakat yang tidak puas dan justru kecewa terhadap pelayanan yang diberikan. Hal tersebut menjadikan pemerintah sebagai penyedia barang publik ataupun jasa publik belum mampu menjawab persoalan-persoalan khususnya di sektor pelayanan publik. Padahal sesuai dengan Undang-Undang Nomor 25 Tahun 2009 tentang Pelayanan Publik mengamanatkan bahwa pemerintah melalui birokrasi ataupun aparatur sipil negara harus senantiasa berupaya untuk semaksimal mungkin bisa meningkatkan kualitas pelayanan publik kepada warga masyarakatnya secara efektif dan efisien. Birokrasi sebagai pelaksana tugas dari pelayanan berhadapan langsung dengan masyarakat sehingga tuntutan tersebut harus dihadapi secara cepat dan akurat (Nurmandi, 2010:13). Oleh karena itu pemerintah harus terus senantiasa berupaya untuk melakukan pembaharuan baik secara sistem, format, 
ataupun proses pelayanan secara komprehensif, salah satunya melalui suatu inovasi pelayanan publik (Risna dan Sundari, 2018:1).

Rendahnya kualitas pelayanan publik mengindikasikan bahwa birokrasi sebagai organisasi publik belum mampu memberikan pelayanan kepada masyarakat secara maksimal. Padahal kinerja organisasi publik yang baik akan mempengaruhi kualitas pelayanan yang diberikan (Dwidowidjoto, 2004:281). Padahal pada era gangguan sekarang ini, organisasi publik pemerintahan didorong untuk menyelenggarakan seluruh tugas dan fungsinya dengan cepat, berkredibilitas, dan memiliki kualitas dalam pelayanan publik (Wibowo, 2019:325). Melihat hal tersebut maka direspon oleh pemerintah pusat melalui kementerian Pendayagunaan Aparatur Negara dan Reformasi Birokrasi yang menegaskan melalui diberlakukannya Peraturan Menteri Pendayagunaan Aparatur Negara dan Reformasi Birokrasi Nomor 9 Tahun 2015 tentang Inovasi Pelayanan Publik.

Guna merespon permasalahan tersebut melalui Peraturan Menteri Pendayagunaan Aparatur Negara dan Reformasi Birokrasi Nomor 9 Tahun 2015 tentang Inovasi Pelayanan Publik maka berbagai instansi pemerintah baik di tingkat pusat atapun daerah gencar menciptakan terobosan-terobosan baru melalui inovasi dalam pelayanan. Salah satu instansi yang menciptakan inovasi tersebut adalah instansi di Dinas Kependudukan dan Pencatatan Sipil Kabupaten Sleman melalui inovasi pelayanan publik bernama "Lukadesi” (Keluarga Berduka Desa Siaga). Inovasi pelayanan publik Lukadesi ini merupakan salah satu cara yang dilakukan oleh Dinas Kependudukan dan Pencatatan Sipil Kabupaten Sleman untuk mewujudkan masyarakat Kabupaten Sleman yang tertib adminitrasi kependudukan.

Hal ini dikarenakan masih banyaknya masyarakat yang belum sadar adminitrasi kependudukan misalnya dalam saat terjadi kematian (Disdukcapil Sleman, 2017). Selain itu dilansir dari http: 
//infopublik.id/kategori/nusantara/295877/sleman-dukung-gerakan indonesiasadar administrasi?show= inovasi ini muncul sebagai sebuah bentuk gebrakan kreatif inisiatif dalam pelayanan publik guna mendukung surat intruksi dari Pemerintah Pusat melalui Kementerian Dalam Negeri tanggal 7 Februari 2018 tentang Gerakan Indonesia Sadar Adminitrasi atau sering disebut GISA. Intruksi ini ditujukan kepada Pemerintah Daerah baik Provinsi ataupun Kabupaten/Kota di Indonesia agar tercipta iklim adminitrasi yang tertib, tertata, dan teratur. Menghadapi persoalan tersebut maka dibentuklah suatu layanan publik yang lebih inovatif dan kreatif yakni melalui inovasi pelayanan publik Lukadesi "Keluarga Berduka Desa Siaga” yang dalam realisasinya mengoptimalkan data kematian dengan mengintegrasikan data secara berjenjang (Dinas Kependudukan dan Pencatatan Sipil Kabupaten Sleman dengan Desa).

Inovasi Lukadesi ini menjadi satu-satunya inovasi di Indonesia yang mampu menumbuhkan kesadaran masyarakat terhadap pentingnya masyarakat yang sadar adminitrasi kependudukan. Oleh karena itu banyak daerah yang melakukan studi banding di Pemerintah Kabupaten Slemaan untuk mempelajari inovasi Lukadesi agar dapat diadopsi di daerah mereka salah satunya Kabupaten Batola Kalimantan Selatan. Berdasarkan permasalahan pelayanan publik yang telah diuraikan di atas, maka perlu dilakukan penelitian dengan judul "Inovasi Pelayanan Publik Lukadesi (Keluarga Berduka Desa Siaga) di Kabupaten Sleman D.I. Yogyakarta".

\section{METODE PENELITIAN}

Penelitian ini menggunakan pendekatan deskriptif kualitatif. Menurut Bungin (dalam Wulandari dkk 2017:67) mengutarakan bahwa metode kualitatif deskriptif yaitu peneliti berusaha merekontruksi atau mendeskripsikan hasil wawancara secara mendalam terhadap sasaran yang akan diteliti atau objek penelitian. Penelitian ini dilaksanakan di Kabupaten Sleman tepatnya di Dinas 
Kependudukan dan Pencatatan Sipil Kabupaten Sleman. Jenis data yang akan dikumpulkan dalam penelitian ini adalah data primer dan data sekunder. Data primer dalam penelitian ini adalah semua informasi mengenai Inovasi Pelayanan Publik Lukadesi (Keluarga Berduka, Desa Siaga) di Dinas Kependudukan dan Pencatatan Sipil Kabupaten Sleman melalui dokumentasi dan wawancara. Penelitian ini mewawancarai setidaknya 8 orang narasumber yakni Kepala Bidang Kependudukan dan Pencatatan Sipil Kabupaten Sleman yakni Ibu Dra Mayawati Jati Lestari, M.T, Bapak Dukuh Sidokarto yakni Bapak Suryanto, Ibu Krismi Nurhayati selaku petugas register kependudukan desa, Fariza selaku ketua komunitas pemerhati pelayanan publik dan empat masyarakat pengguna layanan Lukadesi Kabupaten Sleman. Sementara data sekunder didapatkan melalui dokumen-dokumen, literature, informasi lainya yang relevan seperti LAKIP, IKM, Laporan pelaksanaan Lukadesi.selain itu peneliti dalam menganalisis data secara kualitatif menggunakan teorinya Miles dan Huberman (dalam Masdy dkk, 2017:86) di mana dijelaskan jika dalam mengolah data kualitatif dapat dilakukan dengan menggunakan tiga tahap, yakni tahap reduksi, penyajian data, dan terakhir penarikan kesimpulan berdasarkan langkah tersebut yang telah diuraikan.

\section{HASIL DAN DISKUSI}

Hasil penelitian menunjukkan bahwa inovasi pelayanan publik yang ada di Kabupaten Sleman D.I Yogyakarta menjadi satu-satunya inovasi di bidang pelayanan khususnya dalam menerbitkan surat kutipan akta kematian penduduk secara cepat, bahkan sebelum jenazah dimakamkan maka surat kematianya sudah diserahkan. Di Indonesia sampai saat ini belum ada yang menerapkan inovasi sejenis ini, sehingga inovasi ini menjadi referensi banyak daerah untuk melakukan studi banding di Kabupaten Sleman D.I. Yogyakarta dalam mengimplementasikan inovasi Lukadesi. Berdasarkan hasil temuan di lapangan 
menunjukkan bahwa inovasi pelayanan lukadesi memiliki interval keberhasilan lebih dari 90\% karena di dalam perencanaan Lukadesi sudah disiapkan secara sistematis dan menyeluruh. Mulai dari jumlah pegawai yang memadai, dibentuknya petugas register kependudukan desa di man satu desa dibentuk satu register kependudukan yang kompeten, pelibatan desa-desa mitra Lukadesi, dan juga animo masyarakat yang merespon inovasi ini secara terbuka dan partisipatif.

Selain itu, berdasarkan hasil wawancara oleh Kepala Bidang Kependudukan dan Pencatatan Sipil Kabupaten Sleman sampai saat ini sudah 83 desa dari 86 desa yang ada di Kabupaten Sleman tergabung dalam inovasi Lukadesi. Inovasi ini tidak tiwajibkan, akan tetapi tingginya partisipasi masyarakat di Kabupaten Sleman membuktikan jika mereka memiliki kesadaran dalam bidang administrasi kependudukan yang baik sehingga ini dapat mendukung terwujudnya Kabupaten Sleman sebagai Kabupaten tertib administrasi di Indonesia. Hal ini didukung oleh hasil wawancara terhadap masyarakat Kabupaten Sleman bahwa inovasi ini menjadi kebanggaan masyarakat Kabupaten Sleman dan juga masyarakat terbantu dengan hadirnya inovasi layanan Lukadesi ini. Temuan yang sangat menarik ialah bahwa inovasi ini terencana secara matang mulai dari pemgembangan, kapasitas pegawai, dan juga kecepatan inovasi ini dapat diterima dengan mudah. Oleh karena itu Lukadesi menjadi satu-satunya inovasi di bidang kematian yang ada di Indonesia, sehingga sangat wajar jika banyak daerah di Indonesia yang belajar untuk mengembangkan dan mengadopsinya dalam rangka percepatan penerbitan kutipan akta kematian.

Inovasi pelayanan dapat menciptakan pelayanan publik akan menjadi lebih bagus apabila dilaksanakan dengan baik pula, jangan sampai inovasi hanya mengikuti trend saja sehingga akan musnah pada kemudian. Inovasi harus mampu bertahan dan berkelanjutan agar inovasi dapat bersifat flexible dan mampu menyesuaikan sesuai dengan kebutuhan dan perkembangan masyarakat 
(Putra dkk, 2019:297). Lahirnya inovasi pelayanan publik Lukadesi di Kabupaten Sleman dilatar belakangi oleh rendahnya kesadaran masyarakat terkait administrasi bidang kematian. Hal ini menyebabkan data yang ada di database Dinas Kependudukan dan Pencatatan Sipil tidak sesuai dengan jumlah penduduk di lapangan. Akibatnya, ketika data dari Dinas Kependudukan dan Pencatatan Sipil diadopsi oleh KPUD dalam menetapkan jumlah DPT maka terjadi pemilih hantu ataupun pemilih ganda. Oleh karena itu untuk mengatasi persoalan tersebut dibentuklah oleh Dinas Kependudukan dan Pencatatan Sipil Kabupaten Sleman melalui pelayanan prima dibidang kematian dengan nama Lukadesi.

Berdasarkan hasil wawancara oleh Kepala Bidang Pencatatan Sipil Dinas Kependudukan dan Pencatatan Sipil Kabupaten Sleman inovasi Lukadesi dibentuk pada pertengahan tahun 2017, di mana saat pertama kali dibentuk hanya diikuti oleh satu desa yakni Desa Wukirsari Cangkringan Sleman sebagai pilot project implementasi inovasi Lukadesi. Setelah pelaksanaan dinilai berhasil, maka pada akhir tahun 2017 berawal dari Desa Wukirsari berkembang menjadi Desa Sukoharjo, Desa Tlogoadi, dan Desa Sinduharjo. Jumlah desa peserta Lukadesi tersebut terus meningkat, hingga sampai saat ini per Oktober 2019 sudah tercatat 83 dari 86 desa di Kabupaten Sleman tergabung dalam inovasi pelayanan Lukadesi.

Oleh karena itu pada bagian pembahasan ini akan memfokuskan analisis penelitian terkait dengan bagaimana inovasi pelayanan publik Lukadesi di Dinas Kependudukan dan Pencatatan Sipil Kabupaten Sleman dengan menggunakan teori analisis atribut inovasi pelayanan yang meliputi: relative advantage (keunggulan inovasi), compatibility (kesesuaian dengan kebutuhan masyarakat), complexity (kerumitan), triability (uji publik), dan observability (kemudahan diamati). 


\section{Indikator relative advantage (keuntungan relatif) dalam inovasi pelayanan Lukadesi}

Indikator atribut inovasi relative advantage menilai seberapa jauh nilai kebaharuan atau keunggulan yang melekat dalam sebuah inovasi pelayanan yang tengah diimplementasikan. Oleh karena itu nilai kebaharuan dalam sebuah inovasi akan memberikan manfaat terhadap masyarakat luas terhadap pelayanan tersebut. Nilai kemanfaatan inovasi tersebut dapat diukur dari mungkin nilai ekonominya, kepuasan, status sosial, atau bahkan kesenangan penerimanya dan semua itu merupakan sebuah komponen yang sangat penting dalam pelayanan (Pratiwi, M., \& Syukur, A. T, 2018:141)

Berdasarkan wawancara dengan Kepala Bidang Pencatatan Sipil Disdukcapil Sleman pada tanggal 25 November 2019 menyatakan jika inovasi pelayanan publik Lukadesi memiliki beberapa keunggulan. Pertama, dalam inovasi pelayanan Lukadesi ini adanya respon terhadap peristiwa kematian. Perangkat desa merespon, mengonfirmasi, menanggapi apabila mendengar penduduk atau masyarakat yang meninggal dunia. Pemerintah desa melalui perangkatnya cepat tanggap memberikan pelayananya kepada penduduk yang sedang berduka cita untuk mengurus penerbitan surat akta kematian mengingat penduduk yang sedang berduka sudah lagi tidak sempat mengurus administrasi kematianya, sehingga perangkat desa memiliki peranan penting terhadap kepengurusan administrasi kematianya.

Kedua, nilai kebaharuan dari inovasi pelayanan publik Lukadesi ini adalah pelayanan prima. Ketika terjadi peristiwa kematian maka kehadiran Kepala Desa atau perangkat desa dalam prosesi acara pemakaman sekalian juga langsung menyerahkan surat akta kutipan kematian saat itu juga kepada keluarga yang tengah ditinggalkanya. Hal ini menjadi wujud dari pelayanan prima, di mana terjadi peristiwa kematian maka pelayanan administrasi kematian langsung diterbitkan oleh Dinas Kependudukan dan Pencatatan Sipil dan diserahkan secara 
langsung ke pihak keluarga secara langsung agar kepengurusan administrasi kematian selesai saat itu juga tanpa menunggu waktu yang lama.

Ketiga, adanya pemanfaatan teknologi informasi dalam inovasi pelayanan Lukadesi. Informasi peristiwa kematian secara cepat akan diinfokan melalui WA kepada nomor khusus yang disediakan oleh Dinas Kependudukan dan Pencatatan Sipil dan diproses melalui aplikasi SIDAMPAK (Sistem Data Administrasi dan Kependudukan). Penggunaan teknologi informasi tersebut menjadikan inovasi pelayanan Lukadesi ini menjadi lebih efektif dan efisien tanpa harus datang langsung ke Dinas Kependudukan dan Pencatatan Sipil. Penerapan teknologi informasi menjadi salah satu terobosan baru dalam pelayanan ini agar dapat memaksimalkan inovasi pelayanan Lukadesi yang tengah dijalankan.

Gambar 1. Penyerahan Surat Kutipan Akta Kematian Lukadesi Sebelum

Disemayamkan

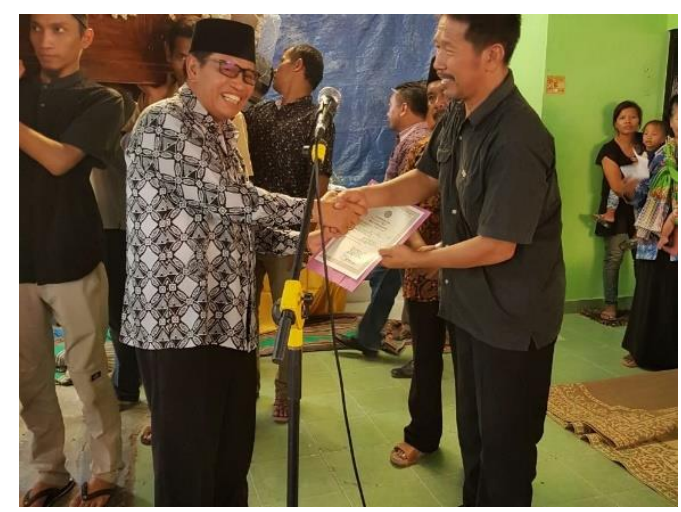

Sumber: Disdukcapil Sleman, 2020

Berdasarkan gambar di atas menunjukkan jika pelayanan Lukadesi Kabupaten Sleman sangatlah cepat di dalam menerbitkan kutipan akta kematian masyarakat dan ini satu-satunya inovasi administrasi kependudukan yang ada di Indonesia.

Keempat, nilai keunggulan dari inovasi pelayanan publik Lukadesi ini adalah adanya komitmen dan perilaku melayani dari petugas register kependudukan desa. Register kependudukan desa yang telah ditunjuk oleh Dinas 
Kependudukan dan Pencatatan Sipil harus siap siaga mengetik dokumen persyaratan kematian walaupun malam atau bahkan pagi untuk dikirim ke aplikasi SIDAMPAK agar Dinas Kependudukan dan Pencatatan Sipil segera menerbitkan surat akta kematian. Terjadinya peristiwa kematian yang terjadi sewaktu-waktu dan terjadi di mana saja menuntut petugas register kependudukan desa untuk siap sedia mengumpulkan dokumen persyaratan akta kematian agar pelayanan administrasi kematian dapat segera dikerjakan secara cepat.

Kelima, nilai lebih dari Lukadesi adalah mampu menerbitkan akta kematian dengan cepat. Pelayanan inovasi Lukadesi pada dasarnya memberikan percepatan penerbitan surat kutipan akta kematian tidak sampai 1 hari, sehingga setelah dokumen yang dikirim oleh petugas register desa dinyatakan lengkap dan terpenuhi maka Dinas Kependudukan dan Pencatatan Sipil tanpa pikir panjang langsung diterbitkan hari itu juga. Target yang dicanangkan dalam penerbitan kutipan akta kematian oleh Dinas Kependudukan dan Pencatatan Sipil yakni 1 hari dengan perpanjangan 3 hari selama berkas belum dinyatakan lengkap.

\section{Indikator compatibility (kesesuaian) dalam inovasi pelayanan Lukadesi}

Indikator kedua dalam atribut inovasi pelayanan publik yaitu compatibility atau kesesuaian. Artinya bahwa munculnya inovasi pelayanan yang baru tidak serta merta meninggalkan konsep pelayanan yang lama dan juga harus ada kesesuaian dengan keadaan masyarakat dan kondisi masyarakat yang ada. Oleh karena itu, indikator kedua ini melihat apakah antara konsep pelayanan yang lama masih digunakan ke dalam konsep inovasi yang baru ini.

Berdasarkan penelitian inovasi pelayanan Lukadesi ini sama sekali tidak meninggalkan konsep dari yang lama, akan tetapi ini berupa konsep terusan yang lebih baik lagi. Pelaksanaan inovasi Lukadesi ini telah dinilai sesuai dengan keadaan kondisi masyarakat. Oleh karena itu masyarakat sangat antusias dengan adanya inovasi ini, bahkan dari 86 desa yang ada di Sleman yang telah tergabung 
dalam inovasi ini sudah ada 83 desa. Dari desa-desa tersebut 3 diantaranya belum menjadi peserta inovasi layanan Lukadesi karena inovasi Lukadesi sifatnya tidak wajib. Ketiga desa tersebut meliputi Desa Pakembinangun, Minomartani, dan Tamanmartani.

Mengacu pada wawancara kepada masyarakat terkait dengan inovasi Lukadesi masyarakat sangat antusias dan mengapresiasi kinerja Pemerintah Kabupaten dalam hal ini Dinas Kependudukan dan Pencatatan Sipil. Masyarakat merasa dimudahkan dengan adanya pelayanan dibidang administrasi kematian yakni penerbitan surat kutipan akta kematian yang sangat cepat, bahkan surat kutipan akta kematian tersebut sudah terbit sebelum jenazah disemayamkan.

Keberadaan Lukadesi di Kabupaten Sleman menjadi layanan unggulan yang ada di desa. Hal ini karena adanya Lukadesi sangat sesuai dengan keadaan masyarakat. Ketika masyarakat baru mengalami peristiwa kematian, maka keadaan mereka sedih, tidak sempat mengurus administrasi kematian. Masyarakat yang berduka hanya fokus kepada kerabat yang meninggal, terkait bagaimana cara menguburkanya dan tidak memungkinkan masyarakat aktif mengurusnya sendiri.

\section{Indikator complexity (kerumitan) dalam inovasi pelayanan Lukadesi}

Indikator yang ketiga dalam atribut inovasi pelayanan adalah terkait kerumitan atau complexity. Hal ini digunakan untuk mengetahui sebuah inovasi pelayanan selain membawa nilai kebaruan juga ada nilai-nilai kerumitan yang melekat dari setiap sistem inovasi pelayanan. Hadirnya inovasi yang lebih baik memungkinkan adanya kerumitan yang muncul tingkatanya lebih besar jika dikomparasikan dengan sistem pelayanan yang lama.

Berdasarkan observasi dan wawancara yang dilakukan oleh peneliti ke Dinas Kependudukan dan Pencatatan Sipil tidak ada kerumitan dalam aspek pelatihan pegawai. Justru pihak Dinas Kependudukan dan Pencatatan Sipil tidak melakukan upaya pelatihan pegawai khusus dalam melaksanakan inovasi 
Lukadesi ini. Hal ini dikarenakan Lukadesi ini tidak berbeda dengan proses ataupun alur kepengurusan penerbitan surat akta kutipan kematian sebelum adanya inovasi ini. Perbedaanya hanya terletak pada adanya petugas register kependudukan desa yang satu desa ada satu orang sementara dulu tidak ada. Selain itu, dalam inovasi pelayanan Lukadesi ini ada penerapan atau penggunaan teknologi informasi berupa WA yang digunakan peregister kependudukan desa untuk bisa mengonfirmasikan dokumen kematian ke pihak Dinas Kependudukan dan Pencatatan Sipil secara cepat dan tepat. Hal tersebut dilakukan sebagai cara untuk mempercepat pelayanan publik. Hal ini dinyatakan oleh Dra Mayawati Jati Lestari., M.T selaku Kepala Bidang Pencatatan Sipil saat wawancara pada tanggal 25/11/2019 yang menyatakan bahwa:

"Prosesnya dalam mengurus kutipan akta kematian itu sama dengan yang dulu, jadi nggak ada pelatihan pegawai yang kita lakukan. Bidang PIAK, Bidang Dafduk, dan Bidang Capil sangat tahu dan kompeten apa yang harus dilakukan kalau mau nerbitkan ini Mas. Soalnya ini itu Lukadesi bukan inovasi yang sama sekali baru, sehingga nggak ada pelatihan dalam menjalankan Lukadesi ini. Desa sudah tahu, kan ini yang ada pembedaan hanya dibentuk petugas register kependudukan desa dan penggunaaan teknologi informasi, udah itu saja, jadi kan justru lebih mudah, dan pelatihan pegawai nggak ada baik di Dinas Kependudukan dan Pencatatan Sipil maupun di bawah Mas"

Selain itu, terkait dengan hal tersebut juga dinyatakan oleh Bapak Edy Suryanto selaku Kepala Dukuh Ngawen Godean Kabupaten Sleman saat diwawancara pada 23/11/2019 yang menyatakan bahwa:

"Lukadesi ini kan sebetulnya dari syarat atau prosedur gitu, nggak beda dari yang lama Mas. Sama persis itu syaratnya Cuma photo copy KTP dan KK. Palingan yang beda di sini ada penggunaan grup WA satu desa satu orang yang masuk grup gitu, jadi nggak ada pelatihan pegawai khusus kalau di tingkat desa sendiri"

Berdasarkan penjelasan di atas maka dari aspek kerumitan maka dalam indikator pelatihan pegawai tidak dilakukan secara sistematis, bahkan tidak ada pelatihan pegawai di dalam melaksanakan Lukadesi. Hal ini dikarenakan 
Lukadesi ini menjadi sistem inovasi pelayanan yang tidak jauh berbeda dari yang lama, hanya yang paling dasar membedakan adalah adanya petugas register kependudukan desa, di mana satu desa hanya ada satu petugas register kependudukan desa. Selain itu, dalam inovasi Lukadesi ini sudah melibatkan teknologi informasi berupa WA di mana pelayanan dulu belum menggunakan teknologi informasi, sehinggga pelatihan pegawai dirasa belum diperlukan.

\section{Indikator triability (uji publik/kemungkinan dicoba) dalam inovasi pelayanan Lukadesi}

Indikator yang keempat dalam sistem atribut inovasi pelayanan adalah triability atau kemungkinan dicoba. Indikator ini menekankan bahwa sebuah inovasi akan dapat diterima oleh publik secara baik apabila inovasi tersebut memberikan perubahan yang mencolok dari adanya inovasi dan sebelum adanya inovasi tersebut. Hadirnya inovasi tersebut dalam prosesnya mampu memberikan solusi-solusi bagi persoalan sebelumnya, sehingga dengan diimplementasikan inovasi tersebut mengikis persoalan lama yang masih menghambat dalam pelayanan publik.

Inovasi pelayanan publik telah mengalami uji coba dan teruji yakni penerapan pertama kali dilakukan di Desa Wukirsari Cangkringan Sleman D.I. Yogyakarta. Desa ini dinobatkan sebagai pilot project Lukadesi di Kabupaten Sleman yang mana sampai saat ini sudah 83 desa dari 86 yang telah tergabung dalam inovasi pelayanan Lukadesi.

Dinas Kependudukan dan Pencatatan Sipil melalui Desa Wukirsari Cangkringan Sleman mengangkat inovasi ini ke level Kabupaten sehingga saat ini Lukadesi menjadi pelayanan unggulan desa. Proses perjalananya dari pelayanan Lukadesi ini melewati proses yang sangat panjang, dari hanya satu desa, berkembang lagi pada akhir tahun 2017 yakni Desa Sukoharjo, Desa Sinduarjo dan Desa Tlogoadi hingga tahun 2018 oleh Dinas Kependudukan dan Pencatatan Sipil dimasifkan lagi agar seluruh desa tergabung dengan pelayanan Lukadesi. 
Pada akhirnya ini terus meningkat hingga sekarang desa yang ada di Kabupaten Sleman 96\% sudah tergabung dalam layanan Lukadesi.

Hadirnya inovasi pelayanan publik Lukadesi dilatarbelakangi karena banyaknya persistiwa kematian di masyarakat yang mana kerabat atau keluarganya tidak aktif melaporkan. Akibatnya, data yang tersimpan di database kependudukan Dinas Kependudukan dan Pencatatan Sipil tidak valid dan muktahir. Artinya dalam database Dinas Kependudukan dan Pencatatan Sipil masih tercantum namanya, akan tetapi yang bersangkutan sudah meninggal dunia. Berawal dari persoalan tersebut maka terciptalah pelayanan Lukadesi dengan setidaknya memiliki tiga tujuan, yakni:

Meningkatkan capaian kepemilikan akta kematian pada peristiwa kematian, maksudnya ketika penduduk atau masyarakat ada yang meninggal dunia maka wajib melaporkanya ke petugas yang bersangkutan dan wajib memiliki surat kutipan akta kematian yang menerangkan bahwa yang bersangkutan telah meningggal dunia dan hilang datanya di database kependududkan Dinas Kependudukan dan Pencatatan Sipil.

Mewujudkan pelayanan prima di mana kutipan akta kematian secara efektif dan efisien dapat diwujudkan dengan memanfaatkan teknologi informasi. Hadirnya teknologi informasi yang melekat pada pelayanan Lukadesi ini menjadi salah satu faktor bahwa pelayanan Lukadesi dapat berjalan secara cepat dari segi waktu, dan efektif tanpa harus datang ke Dinas Kependudukan dan Pencatatan Sipil.

Mewujudkan data kependudukan yang akurat dan mutakhir. Artinya, Lukadesi di samping memberikan sisi positif kepada masyarakat yakni masyarakat dipercepat dan dipermudah dalam mengurus surat kutipan akta kematian, juga di sisi lain memberikan keuntungan bagi Dinas Kependudukan dan Pencatatan Sipil. Data yang dimiliki oleh Dinas Kependudukan dan Pencatatan 
Sipil menjadi lebih akurat, validitasnya teruji sehingga tidak ada terjadi anomali data kematian yang tidak sesuai di lapangan.

\section{Indikator observability (kemudahan diamati) dalam inovasi pelayanan Lukadesi}

Indikator terakhir dalam atribut inovasi pelayanan publik adalah aspek observability atau kemudahan diamati. Indikator terakhir ini digunakan untuk mengetahui apakah dalam sistem inovasi pelayanan itu bekerja dari sisi prosedur ataupun proses mampu dilaksanakan dan dipahami publik dengan cepat dari sisi waktu dan mudah dari sisi prosedur (Hisbani dkk, 2017:268). Tujuanya adalah semata-mata agar masyarakat sebagai sasaran layanan mampu berpartisipasi secara aktif dan responsif terhadap inovasi pelayanan yang akan dilaksanakan. Selain itu, juga adanya pengamatan yang mudah dari sisi proses menjadi bagian dari aspek trasnparansi mengingat jika sebuah kinerja sebuah organisasi memiliki transparansi yang tinggi, otomatis hasilnya juga semakin baik.

Inovasi pelayanan publik Lukadesi secara prosedur pelayanan masih sama seperti yang lama. Penerbitan surat kutipan akta kematian ada beberapa tahapan yang harus terpenuhi seperti kelengkapan dokumen dan juga adanya tanda tangan dari yang bersangkutan sehingga semakin cepat dokumen itu disampaikan ke Dinas Kependudukan dan Pencatatan Sipil maka semakin cepat juga pihak dinas menerbitkanya. Proses ataupun tahapan dalam penerbitan surat kutipan akta kematian dapat dipahami dengan proses sebagai berikut.

Tabel 1. Jenis Pelayanan dan Waktu Penyelesaian Penerbitan Kutipan Akta Kematian Lukadesi

\begin{tabular}{clc}
\hline No & \multicolumn{1}{c}{ Jenis Pelayanan } & Waktu Penyelesaian \\
\hline 1 & $\begin{array}{l}\text { Pengajuan berkas permohonan pencatatan } \\
\text { kematian }\end{array}$ & 2 Menit \\
\hline 2 & $\begin{array}{l}\text { Verifikasi dan validasi data dan informasi } \\
\text { dalam berkas permohonan akta kematian }\end{array}$ & 10 Menit \\
\hline 3 & $\begin{array}{l}\text { Penomoran dan pencatatan dalam register } \\
\text { akta kematian }\end{array}$ & 2 Menit \\
\hline 4 & Penerbitan kutipan akta kematian & 10 Menit \\
\hline
\end{tabular}




\begin{tabular}{clc}
\hline 5 & $\begin{array}{l}\text { Penghapusan biodata penduduk yang } \\
\text { meninggal }\end{array}$ & 5 Menit \\
\hline 6 & Penerbitan Kartu Keluarga (KK) dan KTPel & 15 Menit \\
\hline 7 & $\begin{array}{l}\text { Penandatanganan dan pengesahan oleh } \\
\text { Kepala Dinas: a. Register akta kematian b. } \\
\text { Kutipan akta kematian c. Kartu Keluarga (KK) }\end{array}$ & 10 Menit \\
\hline 8 & $\begin{array}{l}\text { Pemberian stempel dinas pada kutipan akta } \\
\text { kematian dan Kartu Keluarga (KK) }\end{array}$ & 3 Menit \\
\hline 9 & Penulisan di buku register pengambilan dan \\
& penyerahan
\end{tabular}

\section{Sumber: SOP Akta Kematian Disdukcapil Sleman, 2019}

Selain itu, ada standar pelayanan atau SOP yang dijalankan oleh Dinas Kependudukan dan Pencatatan Sipil Kabupaten Sleman dalam menerbitkan surat kutipan akta kematian. Oleh karena itu semakin pemohon cepat dalam memenuhi persyaratan maka penerbitan terhadap surat kutipan akta kematian juga akan semakin cepat dilakukan. Sebaliknya, jika pemohon di dalam melengkapi sdokumen persyaratan masih kurang maka akan diperpanjang selama tiga hari dan bila selama tiga puluh hari terlambat maka yang awalnya akan didenda sebesar Rp. 15.000,00 namun sekarang tidak ada denda dalam kepengurusan admistrasi data kependudukan. Jadi, semakin cepat pemohon menuntaskan persyaratan dalam pengurusan administrasi kematian maka petugas baik di tingkat desa maupun dinas juga akan semakin cepat untuk menindaklanjutinya.

\section{KESIMPULAN}

Berdasarkan uraian di atas maka dapat ditarik beberapa kesimpulan terkait inovasi pelayanan publik Lukadesi yang ada Di Dinas Kependudukan dan Pencatatan Sipil Kabupaten Sleman D.I. Yogyakarta bahwa dari aspek relative advantage, maka dalam inovasi pelayanan Lukadesi ini memiliki lima keunggulan yakni adanya respon terhadap peristiwa kematian. Perangkat desa merespon, mengonfirmasi, menanggapi apabila mendengar penduduk atau masyarakat yang 
meninggal dunia, pelayanan prima, adanya pemanfaatan teknologi informasi dalam inovasi pelayanan Lukadesi, adanya komitmen dan perilaku melayani dari petugas register kependudukan desa dan mampu menerbitkan akta kematian dengan cepat.

Berdasarkan aspek compatibility maka Inovasi pelayanan publik Lukadesi sudah menjawab masalah yang selama masyarakat alami. Masyarakat membutuhkan pelayanan yang cepat, mudah, dan biaya yang murah. Dilihat dari aspek sosialisasi dari inovasi ini maka dapat dikatakan kalau inovasi Lukadesi ini cukup berhasil, karena tanpa dilakukan sosialisasi yang masif masyarakat sudah banyak mengetahui. Berdasarkan jumlah desa yang ada di Kabupaten Sleman yakni 86 Desa maka 83 Desa sudah tergabung dalam inovasi Lukadesi.

Selain itu, dari aspek complexity maka pelaksaaan inovasi Lukadesi ini tidak ada hambatan yang berarti, baik dari sisi pelatihan pegawai maupun dari sisi anggaran. Dilihat dari sisi kerumitan pelatihan pegawai, maka dalam pelaksanaan inovasi pelayanan publik Lukadesi ini dinilai bahwa kinerja pegawai sudah kompeten dan tahu apa yang harus dilakukan sehingga tidak harus ada pelatihan pegawai khusus baik dari Dinas Kependudukan dan Pencatatan Sipil maupun di tingkat desa. Selain itu, dari aspek kerumitan anggaran maka tidak ada biaya khusus yang dialokasikan oleh Dinas Kependudukan dan Pencatatan Sipil mengingat inovasi pelayanan ini bukan baru sama sekali, hanya ada modifikasi sedikit yang justru membuat pelayanan ini menjadi lebih efektif dan lebih efisien.

Selanjutnya dari aspek triability maka Inovasi Lukadesi ini sudah memenuhi atribut tersebut. Hal ini dikarenakan inovasi ini sebelum diimplementasikan telah teruji di Desa Wukirsari Cangkringan Sleman yang telah memberikan dampak positif bagi Dinas Kependudukan dan Pencatatan Sipil Kabupaten Sleman dan juga bagi Pemerintah Desa sendiri, sehingga inovasi ini dimasifkan dan diangkat ke level kabupaten oleh Dinas Kependudukan dan Pencatatan Sipil Kabupaten Sleman. Selain itu, dari sisi kepuasan masyarakat 
sangat baik. Hal ini dinyatakan oleh masyarakat sendiri yang merasa puas terhadap inovasi Lukadesi. Perasaan puas tersebut tercermin dari IKM 2018 Dinas Kependudukan dan Pencatatan Sipil Kabupaten Sleman yang berpredikat "BAIK".

Sementara dari aspek observability maka Inovasi pelayanan publik Lukadesi di dalam tahapanya masih sama dengan tahapan ataupun SOP pada sistem pelayanan yang lama. Oleh karena itu semakin pemohon cepat dalam memenuhi persyaratan maka penerbitan terhadap surat kutipan akta kematian juga akan semakin cepat dilakukan.

Berdasarkan hasil riset tersebut maka peneliti memberikan beberapa rekomendasi yakni Dinas Kependudukan dan Pencatatan Sipil perlu membuka ruang yang seluas-luasnya terhadap inovasi Lukadesi kepada masyarakat agar inovasi pelayanan publik Lukadesi tidak dibatasi transparansinya, Dinas Kependudukan dan Pencatatan Sipil harus memasifkan pelayanan Lukadesi ke 86 desa yang ada di Kabupaten Sleman karena baru hanya ada 83 desa yang bermitra dengan Lukadesi dan terkait sosialisasi, perlu digalakkan secara masif agar seluruh desa yang ada di Kabupaten Sleman segera bergabung dalam inovasi pelayanan publik Lukadesi

Peneliti menyadari bahwa penelitan yang dilakukan dengan kasus pelayanan publik Lukadesi di Kabupaten Sleman sangat jauh dari kata sempurna, sehingga penulis sangat membuka kritik dan saran terhadap penelitian kedepanya agar hasil penelitian dapat lebih baik lagi. Saran bagi pembaca tulisan ini agar dijadikan sebagai referensi untuk bisa membangun sistem pelayanan publik yang inovatif untuk menciptakan kualitas pelayanan publik. 


\section{REFRENSI}

Ariyani, O. P. (2020). Inovasi Pelayanan Publik Suroboyo Bis di Kota Surabaya. JPSI (Journal of Public Sector Innovations), 5(1), 23-30.

Choiriyah, I. U., \& Chabibi, M. Y. (2020). Keuntungan Relatif dalam Inovasi Pelayanan Pengaduan Kerusakan Jalan Melalui Aplikasi M-Bonk. JKMP (Jurnal Kebijakan dan Manajemen Publik), 6(2), 149-153.

Djamrut, D. E. (2015). Inovasi Pelayanan Publik Di Kecamatan Sungai Kunjang Kota Samarinda. Universitas Mulawarman, Samarinda. Hal, 1472-1486.

Dwidowidjoto, R, N. (2004). Kebijakan Publik: formulasi, Implementasi, dan Evaluasi. Jakarta: PT Elex Media Komputindo Kelompok Gramedia.

Fitriana, D. N. (2014). Inovasi Pelayanan Publik BUMN (Studi Deskriptif tentang Inovasi Boarding Pass System dalam Meningkatkan Kualitas Pelayanan Kereta Api PT KAI di Stasiun Gubeng Surabaya).

Hisbani, N. A., Karim, M., \& Malik, I. (2017). Penerapan Inovasi Pelayanan Publik Di Dinas Kependudukan Dan Catatan Sipil Kabupaten Enrekang. Kolaborasi Jurnal Administrasi Publik, 1(3).

Jati, W. R. (2012). Inovasi Pelayanan Publik Setengah Hati Studi Pelayanan Publik di SAMSAT Kota Yogyakarta. Jurnal Ilmu Sosial dan Ilmu Politik, 15(1), 6878.

Masdy, N.A., Haerani, Siti., Alam, A.S. (2017). Peran Pemerintah Daerah Terhadap Pemberdayaan Pemuda Dalam Pengembangan Sektor Pariwisata Di Kabupaten Barru (Pantai Ujung Batu). Jurnal Analisis Seri-seri Ilmu Sosial, 6(1), 84-91.

Nurmandi, A. (2010). Manajemen Pelayanan Publik. Sinergi Publishing.

Putra, A., Usman, J., \& Abdi, A. (2018). Inovasi Pelayanan Publik Bidang Kesehatan Berbasis Home Care Di Kota Makassar. Kolaborasi Jurnal Administrasi Publik, 3(3), 294-309.

Pratiwi, M., \& Syukur, A. T. (2018). Inovasi Pelayanan Publik studi Kasus "Motor Pelayanan Lorong Ta" Pada Kantor Kecamatan Rappocii Makassar. Jurnal Administrasi Negara, 24(3), 139-148.

Risna, R., \& Sundari, M. (2018). Pelaksanaan Pelayanan Publik (Studi Kasus Pelayanan Administratif di Kantor Desa Kotabaru Seberida Kecamatan Keritang Kabupaten Indragiri Hilir). Jurnal Online Mahasiswa Fakultas Ilmu Sosial dan Ilmu Politik Universitas Riau, 5(1), 1-10.

Suwarno, Y. (2008). Inovasi di Sektor Publik. STIA-LAN, Jakarta.

Wibowo, I. T. (2019). Proses Difusi Inovasi Program Sakti (Studi Kasus Proses Difusi Inovasi Program Sistem Aplikasi Keuangan Tingkat Instansi (SAKTI) Ditjen Perbendaharaan di DI Yogyakarta Tahun 2018). Indonesian Treasury Review: Jurnal Perbendaharaan, Keuangan Negara dan Kebijakan Publik, 4(4), 323-337. 
Wulandari, Dewi., Unde, A. Alimuddin., Fatima, Jeanny Maria. (2017). Kemampuan Adaptasi Integrasi Pedagang Jawa Dengan Pedagang Lokal Pasar Tradisional Di Kota Makassar. Jurnal Analisis Seri-seri Ilmu Sosial, 6(1), 65-71.

Permenpan Nomor 9 Tahun 2015 Tentang Inovasi Pelayanan Publik UU Nomor 23 Tahun 2014 Tentang Pemerintahan Daerah UU Nomor 25 Tahun 2009 Tentang Pelayanan Publik https://depokkec.slemankab.go.id/penyerahan-akta-kematian-program-lukadesi.slm https://dukcapil.slemankab.go.id/lukadesi-untuk-masyarakat-sleman.slm https://kalsel.antaranews.com/berita/128235/batola-pelajari-pelayanan-lukadesisleman

https://ngemplakkec.slemankab.go.id/dinas-dukcapil-sleman-siap-laksanakan-programluka-desi/

https://v7.baritokualakab.go.id/?p=7069

https://www.suaramerdeka.com/news/baca/125334/pembuatan-akta-kelahiran-dankematian-dipermudah

http://infopublikid/kategori/nusantara/295877/sleman-dukung-gerakan-indonesiasadar-administrasi?show $=$

\section{Wawancara}

Lestari, Mayawati Jati. (2019). Dinas Kependudukan dan Pencatatan Sipil Kabupaten Sleman, 23 November 2019

Suryanto. (2019). Kepala Dukuh Ngawen Godean Sleman, 25 November 2019

Nurhayati, Krismi. (2019). Kasi Pemerintahan Umum Desa Sidokarto, 25 November 2019

Ikhsanditya, Fariza. (2019). Ketua Pemuda Sidokarto, 29 November 2019

Prasetyo, Rahmad. (2019). 30 November 2019

Setiawan, Arip. (2019). 30 November 2019

Cahyadi, Wachid Nur. (2019). 30 November 2019 